\title{
IMPLEMENTASI KERAHASIAAN INFORMASI MEDIS DALAM REKAM MEDIS PASIEN ( Studi Kasus di Rumah Sakit Islam AT-TIN HUSADA Ngawi Jawa Timur )
}

\author{
Budhi Rahardjo \\ Prodi. Ilmu Kesehatan Masyarakat, FKM, Universitas Veteran Bangun Nusantara \\ Email: budhirahardjo8@gmail.com
}

\begin{abstract}
The implementation of the confidentiality of medical record documents at RSI AT-Tin Husada Ngawi which is still not kept confidential, it can be seen from the patient's medical record documents in the insurance department and in the BPJS unit more than 24 hours for claims purposes, the medical records of inpatients should be $2 \times 24$ hours must be returned to the medical record unit.

This type of research is descriptive qualitative. The study was conducted at RSI AT-Tin Husada Ngawi in September 2018. The subjects were medical records officers, doctors and patients, using the Observation and Interview method, using a retrospective and the technique used was purposive sampling. The population here is the medical records of patients and doctors, data analysis with flow models.

The results of research at RSI AT-Tin Husada Ngawi, there are 3 ownership of medical record documents in the Hospital, namely: Belonging to the hospital, public property or third party property, owned by the patient. The information the doctor gives the patient about the patient's illness is clear and before medical treatment the patient must complete the informed consent form. But to protect the rights of patients to the confidentiality of the contents of medical records at RSI AT-Tin Husada Ngawi, it is not yet in accordance with the Minister of Health Regulation No.269/Menkes/Per/III/2008.

It is recommended that RSI AT-Tin Husada Ngawi need a clear and clear SOP about the return of medical record files.

Keywords: Protection of Patient Rights, Confidentiality of Medical Information, Giving Medical Information
\end{abstract}

\section{ABSTRAK}

Kerahasiaan rekam medis secara umum telah disadari bahwa informasi yang didapat bersifat rahasia, karna didalam dokumen rekam medis menjelaskan hubungan khusus antar dokter dan pasien. Di RSI AT-Tin Husada ngawi dokumen rekam medis berada diunit BPJS dan asuransi. Bagimana perlaksanan perlindungan kerahasiaan informasi medis di RSI AT-Tin Husada Ngawi.

Jenis penelitian ini adalah Deskriptif Kualitatif. Penelitian dilakukan di RSI AT-Tin Husada Ngawi pada September 2018. Subyek penelitian adalah petugas rekam medis, dokter dan pasien, variabel penelitian kepemilikan rekam medis, hak pasien atas informasi medis, hak pasien atas oenjagaan informasu medis, dengan menggunakan metode Observasi dan Wawancara, dengan menggunakan Retrospektif dan Tehnik yang digunakan adalah Purposive Sampling. Populasi disini adalah petugas rekam medis pasien dan dokter, analisis data dengan model alir.

Hasil penelitian di RSI AT-Tin Husada Ngawi, kepemilikan dokumen rekam medis di Rumah Sakit ada 3, yaitu: Milik rumah sakit, milik umum atau milik pihak ketiga, milik pasien. Informasi yang diberikan dokter kepada pasien tentang penyakit pasien sudah jelas dan sebelum dilakukan tindakan medis pasien harus mengisi lembar informed consent. Tetapi untuk perlindungan hak pasien atas kerahasian isi rekam medis di RSI AT-Tin Husada Ngawi belum sesuai Permenkes No 269/Menkes/Per/III/2008.

Disarankan kepada RSI AT-Tin Husada Ngawi perlu adanya SOP yang jelas dan tegas tentang pengembalian berkas rekam medis.

Kata kunci: Perlindungan Hak Pasien, Kerahasiaan Informasi Medis, Pemberian Informasi Medis. 


\section{PENDAHULUAN}

Penyelenggaraan rekam medis yang baik bukan hanya untuk keperluan medis dan administrasi, tetapi juga karena isinya sangat diperlukan oleh individu dan organisasi yang secara hukum berhak untuk mengetahuinya.Pasien berhak untuk meminta informasi medis kepada dokter yang memberikan pelayanan dan tindakan medis kepadanya, dalam isi dokumen rekam medis pasien, dokter harus mempertimbangkan setiap situasi dan kondisi pasien. Jika kondisi pasien tidak mendukung untuk mendapatkan informasi medis, maka dokter dapat menahan informasi tersebut dan menyampaikannya kepada keluarga pasien, rumah sakit bertanggung jawab secara moral dan legal terhadap informasi tersebut, dengan demikian rumah sakit perlu melindungi hak-hak pasien atas informasi didalam rekam medisnya (Firdaus, 2010).

Kerahasiaan rekam medis secara umum telah disadari bahwa informasi yang didapat dari rekam medis sifatnya rahasia.Informasi rekam medis bersifat rahasia karena hal ini menjelaskan hubungan yang khusus antara pasien dengan dokter, yang wajib dilindungi sesuai dengan kode etik kedokteran dan peraturan perundang-undangan yang berlaku. Kerahasiaan dokumen rekam medis merupakan faktor penting dalam sistem pelayanan rekam medis, karena dokumen rekam medis merupakan media komunikasi antara dokter dengan pasien tentang riwayat penyakit yang dideritanya. Beberapa hal yang berkaitan dengan aspek hukum rekam medis yaitu kerahasiaan rekam medis, kepemilikan rekam medis, keamanan rekam medis, informed consent, dan lama simpan rekam medis (Depkes RI 2006).

Kerahasiaan informasi medis sangat penting karena apabila ada informasi medis pasien sampai ke publik atau orang lain tanpa seizin pasien maka hak tersebut termasuk perbuatan melanggar HAM. Sering kita mendengar berita di media cetak maupun media elektronik, ada korban atau pasien yang mengadukan masalah tentang pembeberan rahasia medik, tentu permasalahan ini sangatlah tidak diinginkan padahal masalah ini sebenarnya dapat dicegah dengan adanya pengawasan, penyimpanan dan pelindungan yang tepat pada dokumen rekam medis (Depkes RI 2006).
Realita tentang adanya pelindungan terhadap privasi pasien dapat digambarkan dalam kasus yang dialami oleh sepasang suami istri di kecamatan Sepaku dan kecamatan Bahulu, Kabupaen Penajam Paser Utara, mereka di usir warga setempat karena mengidap HIV/AIDS. Terkait dengan keadilan tersebut patut dipertanyakan: mengapa status HIV/AIDS mereka dapat diketahui masyarakat? Itu artinya ada yang membocorkan atau membeberkan status HIV/AIDS sepasang suami istri status HIV/AIDS, mereka sudah termasuk melakukan perbuatan yang melawan hukum dan pelanggaran perhadap Hak Asasi Manusia (HAM) yang diancam dengan sanksi pidana atau sanksi kurungan (Indarwati 2011).

Dalam penelitian ini ditemukan permasalahan yaitu pelaksanaan kerahasiaan dokumen rekam medis di Rumah Sakit Islam AT-Tin Husada Ngawi yang masih belum terjaga kerahasiaannya, hal itu terlihat dari dokumen rekam medis pasien berada di bagian asuransi lebih dari $2 \times 24$ jam untuk keperluan proses klaim asuransi dan di unit BPJS 2x 24 jam untuk keperluan klaim BPJS, Karena seharusnya prosedur peminjaman dokumen rekam medis pasien rawat jalan 1x 24 jam dan untuk dokumen rekam medis pasien rawat inap 2x 24 jam harus dikembalikan lagi ke unit rekam medis (Pedoman Rekam Medis DEPKES RI 2006). Oleh karena itu alasan peneliti mengambil penelitian di Rumah Sakit Islam AT-Tin Husada Ngawi karena penulis ingin mengetahui tentang pelaksanaan perlindungan kerahasiaan informasi medis di rumah sakit tersebut penelitian ini berjudul Analisis Kerahasiaan Informasi Medis Dalam Rekam Medis Pasien di Rumah Sakit Islam AT-.Tin Husada Ngawi Tahun 2018.

\section{METODOLOGI PENELITIAN}

Penelitian ini menggunakan metode penelitian Deskriptif Kualitatif yaitu suatu metode penelitian yang dilakukan dengan tujuan utama untuk membuat gambaran atau deskripsi tentang suatu keadaan secara objektif (Notoatmodjo, 2005).

Metode yang digunakan dalam penelitian ini adalah metode observasil pengamatan dan wawancara. Observasi adalah suatu prosedur yang berencana, yang antara lain meliputi melihat dan mencatat jumlah dan taraf aktivitas tertentu yang ada hubungannya dengan 
masalah yang diteliti (Notoatmodjo, 2005), sedangkan wawancara adalah suatu metode yang dipergunakan untuk mengumpulkan data, dimana peneliti mendapatkan keterangan atau pendirian secara lisan dari seseorang sasaran penelitian (responden), atau bercakap-cakap berhadapan muka dengan orang tersebut (Notoatmodjo, 2005).

Dilihat dari pendekatannya,maka penelit ian menggunakan metode penelitian restrospektif. Waktu penelitian dilaksanakan pada bulan September 2018 Lokasi penelitian di Rumah Sakit Islam AT-Tin Husada Ngawi.

Populasi adalah keseluruhan objek penelitian atau objek yang diteliti (Notoatmodjo, 2005). Populasi dalam penelitian ini adalah seluruh pasien di semua poli dan rawat inap di Rumah Sakit Islam AT-Tin Husada Ngawi yang buka setiap hari, jumlah dokter, petugas rekam medis, dan pasien rawat jalan maupun rawat inap. Sampel adalah sebagian yang diambil dari keseluruhan objek yang diteliti atau dianggap mewakili dari keseluruhan populasi (Notoatmodjo, 2005). Untuk menentukan sampel yang akan digunakan dalam penelitian, terdapat berbagai teknik sampling yang digunakan yaitu probability sampling atau Non Random sampling (Notoadmojo, 2005). Teknik pengambilan sampel yang digunakan menggunakan purposive sampling adalah pengambilan sempel secara purposive didasarkan pada suatu pertimbangan tertentu yang dibuat oleh peneliti sendiri, berdasarkan ciri atau sifat populasi yang sudah di tentukan sebelumnya (Notoadmojo, 2005). Pengambilan sampel diatas dengan cara Purposive Sampling didasarkan pada suatu pertimbangan tertentu yang dibuat oleh peneliti.

Pengolahan data dilakukan dengan cara Collecting yaitu proses pengumpulan data dari hasil observasi yang telah dilakukan. Editing yaitu periksaan kembali data-data yang sudah dikumpulkan sesuai dengan tujuan penelitian. Penyajian data yaitu data yang telah disajikan dalam bentuk informatif menganalisa deskriptif.

\section{HASIL}

Tempat penelitian di RS. Islam AT-Tin Husada Ngawi yaitu dari sekian rumah sakit milik swasta atau lainya ngawi berwujud RSU, di urus olehh yayasan At-Tin Husada Islam yang tergolong dalam rumah sakit tipe C. Rumah sakit islam At-Tin Husada ini didirikan dengan niat ibadah dn sosial untuk memenuhi kebutuhan masyarakat kabupaten ngawi khususnya dan kota yang ada di sekitarnya akan layanan kesehatan yang paripurna. Rumah sakit islam At-Tin Husada Ngawi telah terdaftar sejak 28/04/2015 dengan Nomor Surat ijin 503001404.209/2014. Berdiri di atas tanah yang terletak strategis yaitu jalur ngawi solo dan seluas kurang lebih 5 Hektar (namun baru di gunakan kurang lebih 2.1 Hektar). Rumah Sakit Islam AT-TIN HUSADA di Kabupaten Ngawi termasuk kategori Rumah Sakit Tipe C. Dengan fasilitas Instalasi Rawat Jalan (IRJA) dengan 15 Pelayanan Spesialis dan Sub Spesialis dan Instalasi Rawat Inap (IRNA) kapasitas tempat tidur 175 buah terdiri dari tiga lantai yang terbagi atas pelayanan VVIP, VIP, Kelas Utama, Kelas I, Kelas II, Kelas III dan IGD, ICU, IHC, PICU, NICU, VK serta dilengkapi dengan laboratorium lengkap dan canggih, radiologi (CT Scan, USG 4 Dimensi) dan 3 ruang operasi yang bersinergi, dan rencana dalam pengembangan akan disiapkan fasilitas Hemodialisa 20 unit. Dengan perkembangan kondisi masyarakat pada saat ini, maka Rumah Sakit Islam AT-TIN HUSADA di Kabupaten Ngawi diharapkan dapat memberikan layanan kesehatan kepada masyarakat sekitarnya secara profesional dengan biaya yang terjangkau.

1. Deskriptif Pelaksanaan Perlindungan Kerahasiaan Informasi Medis Terhadap Hak-Hak Pasien Atas Pemberian Informasi Medis Pasien di Rumah Sakit Islam AT-Tin Husada Ngawi

Berdasarkan wawancara kepala Rekam Medis di Rumah Sakit Islam AT-Tin Husada Ngawi mengenai perlindungan kerahasiaan informasi medis terhadap hak- hak pasien atas pemberian informasi medis pasien di Rumah Sakit Islam AT-Tin Husada Ngawi penulis memperoleh beberapa informasi, diantaranya:

a. Kepemilikan Dokumen Rekam Medis Pasien di Rumah Sakit Islam AT-Tin Husada Ngawi.

Wawancara yang dihasilkan dari kepala Rekam Medis di Rumah Sakit Islam AT-Tin Husada Ngawi yang bernama ibu x pada hari Rabu tanggal 24 September, Unit Rekam Medis di Rumah Sakit Islam AT-Tin Husada Ngawi terdiri dari 7 petugas Rekam Medis, kepemilikan dokumen rekam medis itu ada 3 yaitu: milik rumah sakit, milik umum, milik pasien. 
1). Milik Rumah Sakit itu dokumen rekam medis milik rumah sakit atau pelayanan kesehatan, mengingat segala catatan yang terdapat dalam dokumen rekam medis merupakan ringkasan pelayanan kepada pasien itu untuk bukti rumah sakit untuk penyembuhan pasien.

2). Milik Umum itu dimana dokumen rekam medis di perlukan untuk pihak ketiga misalnya asuransi, pengadilan, dan kepolisian untuk visum.

3). Milik Pasien itu isi dari dokumen rekam medis itu milik pasien dari identitas, riwayat penyakit, pengobatan, sampek tindakan yang dilakukan dokter. Semua itu harus dijaga kerahasiaannya, jika ada yang meminta harus seijin pasien dan menandatangani surat persetujuan pelepasan informasi.

"Sumber Petugas Rekam Medus Pernyataan No 3 : Yang berhak meminta itu ya pasiennya Karena rekam medis itu milik rumah sakit dan isinya milik pasien mbak. Jika pihak asuransi atau pihak ke tiga meminta ya harus dengan persetujuan pasien, itu menggunakan surat kuasa di dalamnya berisi suatu persetujuan pasien dan ditunjukkan kepada direktur rumah sakit kalau sudah ditandatangani baru kepetugas $\mathrm{RM}$ baru bisa ke pihak ke tiga untuk pelepasan informasi, dan itu pun harus disertai dengan kuwitansi pembayaran."

"Sumber Dokter Pernyataan No 2: Dengan cara menjaga semua informasi pasien tanpa memberitahukan ke pihak lain ataupun pihak ketiga tanpa persetujuan pasien. Karna itu kaitannya tentang etika profesi kedokteran mbak, sama komite medik sendiri untuk menjaga kerahasiaan kepada orang lain, setatus pasien yang berhak tau hanya pasien, dokter dan perawat dan penyimpanan di percayakan kepada petugas rekam medis, selain itu tidak boleh ada yang mengetahuinya tanpa seijin pasien."

b. Mengetahui Hak Pasien atas Informasi Medis dalam Rekam Medis di Rumah Sakit Islam AT-Tin Husada Ngawi.

Wawancara yang penulis lakukan dengan kepala Rekam Medis yang bernama ibu x, 1 dokter dan 25 pasien di Rumah Sakit ATTin Husada Ngawi, pada hari kamis tanggal 25 September Jam 14.00, Informasi yang diberikan dokter atau tenaga medis kepada pasien yaitu riwayat tentang penyakit pasien, tingkat keparahan penyakitnya, tindakan apa yang harus diambil, resiko, tujuan pengobatan apa saja yang diberikan dan dalam jangka waktu berapa lama. Semuanya itu harus diinformasikan kepada pasien karena pasien berhak tahu tentang keadaan atau kondisi penyakitnya. Selain itu dokter juga harus selalu memberikan informasi dengan sejujur-jujurnya dengan bahasa yang dimengerti dan mudah dipahami pasien.

"Sumber Petugas Rekam Medis Prnyataan No 4 : Tidak semua isi dokumen diberitahukan yang di beritahukan hanya terbatas yaitu : Ringkasan keluar (resume) yang berisi; identitas, diagnosa pada saat dirawat, diagnosa akhir, pingkasan riwayat penyakit, pemeriksaan fisik, hasil laboratorium, keadan pasien, pengobatan, kesimpulan pada saat pasien keluar."

"Sumber Dokter Pernyataan No 1: Informasi tentang penyakit yang pasien derita dan segala hal yang berhubungan dengan sakitnya, tindakan apa yang saya lakukan dan resikonya apa yang akan terjadi itu.

"Sumber Dokter Pernyataan No 3: Antara lain disini: diagnosis, dasar diagnosis. Tindkan kedokteran, indikasi kedokteran, tatacara, tujuan dan resiko, komplikasi, prognosa. Pasien disini kan berhak tau apa yang di derita mbak, maksudnya keadaan penyakitnya saat ini bagai mana terus tindakan yang diambil bagai mana dan pengobatan apa yang diberikan, jangka waktunya sampai selesainya berapa, dan itu di informasikan dalam bentuk lisan."

"Sumber Pasien 19: yang diberitahu tentang penyakit saya dik."

Prosedur pemaparan isi rekam medis Menurut Pedoman penyelenggaraan dan Prosedur Rekam Medis Rumah Sakit Departemen Kesehatan RI (2006) yaitu:

1) Informasi yang mengandung nilai kerahasiaan

Informasi yang mengandung nilai kerahasiaan di Rumah Sakit Islam AT-Tin Husada Ngawi terdiri dari diagnosa pasien, anamnesa, perjalanan penyakit, catatan perawat, hasil pemeriksaan laboratorium atau rontgen, ringkasan keluar dan resume keperawatan. Semua hal yang berhubungan dengan diri pasien sedangkan pemberitahuan tentang penyakit pasien kepada keluarga harus dilakukan oleh dokter yang merawat.

2) Informasi yang tidak mengandung nilai kerahasiaan

Informasi yang tidak mengandung nilai kerahasiaan di Rumah Sakit Islam Ngawi terdiri 
dari identitas pasien seperti nama, alamat, tanggal lahir, pendidikan, agama, pekerjaan dan lain-lain yang tidak mengandung nilai medis, walaupun demikian informasi ini juga tidak boleh dipublikasikan tanpa izin dari pasien. Informasi yang diperoleh pasien dari dokter atau tenaga medis disampaikan secara lisan dan ada pula yang disampaikan secara tertulis tetapi untuk tindakan tertentu saja. Pasien memperoleh informasi tentang keadaan penyakit yang dideritanya selain itu pasien juga dimintai persetujuan tindakan yang akan dilakukan oleh dokter atau tenaga medis dalam bentuk informed consent yaitu surat persetujuan tindakan.Kebijakan yang dilakukan di Rumah Sakit Islam AT-Tin Husada Ngawi mengenai informed consent yaitu:

1) Informed consent harus ada untuk tindakan medis tertentu pada pasien.

2) Informed consent dilakukan oleh dokter dengan terlebih dahulu memberikan penjelasan kepada pasien, kemudian pasien, dokter, saksi-saksi menandatangani persetujuan dan dokter melakukan tindakan medis paling lambat 24 jam setelah ditandatangani.

Prosedur persetujuan tindakan medis Informed Consent di Rumah Sakit Islam AT-Tin Husada Ngawi yaitu:

1) Disediakan Informed Consent yang Berisi: a) Penjelasan singkat yang dilakukan. b) Identitas pasien dan keluarga.

2) Kolom tanda tindakan yang akan dilaksanakan untuk pasien keluarganya dan dokter yang melaksanakan tindakan.

3) Sebelum tindakan dilaksanakan pasien atau keluarga suruh membaca Informed Consent, sehingga dapat memahami makn dan tujuan tndakan yang akan dilaksanakan, apabila keluarga tidak dapat membawa maka perawat yang akan menjelaskan makna dan tujuan Informed Consent.

4) Keuntungan, kerugian dan efek samping dari tindakan dijelaskan oleh dokter yang akan melaksanakan tindakan.

5) Apabila pasien setuju, maka pasien menandatangani kolom persetujuan tindakan oleh perawat sebagai saksi dokter yang melakukan tindakan.

6) Setelah bukti tertulis baru dapat dilaksanakan tindakan medis. c. Perlindungan Hak Pasien atas Penjagaan Kerahasiaan isi Rekam Medis di Rumah Sakit Islam AT-Tin Husada Ngawi.

Berdasarkan wawancara dengan kepala Rekam Medis di Rumah Sakit Islam AT-Tin Husada Ngawi yang bernama ibu x, 1 Dokter, dan 25 pasien, pada hari Rabu tanggal 24 September 14.00, Cara petugas rekam medis untuk menjaga dan melindungi kerahasiaan dokumen rekam medis yaitu dengan cara:

\section{1) Hak Tolak Ungkap}

Informasi yang didapatkan bahwa dokumen rekam medis harus dijaga kerahasiaannya dan tidak boleh dibaca atau diketahui oleh orang lain tanpa seijin pasien dangan yang boleh mengetahui hanya petugas yang berwenang.

2) Hak Akses

Informasi yang didapatkan bahwa pasien boleh mengcopy data-data rekam medisnya sendiri untuk keperluan asuransi atau visum menandatangani surat pelepas informasi.

3) Hak untuk mendapatka informasi yang berkaitan dengan kondisi dan tindakan yang akan dilakuan terhadap dirinya.

Berdasarkan hasil wawancara yang dilakukan bahwa pasien mendapatkan informasi tentang kondisi dan tindakan yang akan dilakuakan oleh dokter atau tenaga medis lainya.

4) Hak Privasi

Berdasarkan hasil wawancara yang dilakukan bahwa pasien mendapatkan haknya atas privasinya yaitu hubungan antara dokter dan pasien.

Berdasarkan observasi yang penulis lakukan pada hari kamis tanggal 24 September Jam 14.00, pendistribusian berkas rawat jalan sudah diterapkan sesuai aspek hukum, sebagai contoh setelah pasien mendaftar, dokumen pasien langsung dicarikan petugas RM lalu diberikan kepada poli yang di tuju oleh petugas Rekam medis.

Masalah yang ditemukan disini adalah pada saat pengembalian dokumen rekam medis. Pengambilan dokumen rekam medis tidak langsung ke unit filing tapi ke unit BPJS dan Asuransi, karena sebagian dokumen rekam medis pasien pulang yang menggunakan BPJS ataupun Asuransi belum di kembalikan sesuai peraturan, yaitu 2x 24 jam. Sehingga pengambilan ataupun pencarian dokumen rekam medis pada saat pasien kontrol post rawat inap belum berada di unit rekam medis atau di rak filling. Hal tersebut tidak sesuai dengan Depkes RI 2006 karena dokumen rekam medis 
pasien rawat inap dalam pengembalian lebih dari 2x 24 jam.

\section{PEMBAHASAN}

a. Kepemilikan Dokumen Rekam Medis Pasien di Rumah Sakit Islam AT-Tin Husada Ngawi.

Berdasarkan hasil wawancara yang telah dilakukan dengan petugas URM di Rumah Sakit Islam AT-Tin Husada Ngawi diperoleh informasi bahwa dokumen rekam medis ada tiga macam kepemilikannya yaitu:

1. Milik Rumah Sakit

Hasil wawancara di Rumah Sakit dokumen milik rumah sakit atau pelayanan kesehatan, segala catatan yang terdapat dalam dokumen merupakan ringkasan pelayanan pasien. Tersebut sudah sesuai dengan pasal 12 ayat 1 permenkes RI No.269/Menkes/per/III/2008 milik rumah sakit atau sarana pelayanan kesehatan, hal ini mengingat segala catatan yang terdapat dalam berkas rekam medis merupakan rangkaian kegiatan pelayanan yang diberikan oleh unit pelayanan kepada pasien, jadi bukti dokumentasi tersebut adalah sebagai tanda bukti rumah sakit terhadap segala upaya dalam penyembuhan pasien.

\section{Milik Umum}

Milik Umum adalah adanya keperluan pihak ketiga serta badan asuransi dan pengadilan. Berdasarkan hasil wawancara di Rumah Sakit dimana dokumen rekam medis di perlukan untuk pihak ketiga misalnya asuransi, pengadilan, dan kepolisian untuk visum. Hal tersebut sudah sesuai dengan Depkes RI (2006) Rekam Medis menjadi milik umum karena adanya minat pihak ketiga serta badan-badan asuransi dan pengadilan.

\section{Milik Pasien}

Berdasrkan hasil wawancara di Rumah Sakit dokumen rekam medis itu milik pasien dari identitas, tindakan, riwayat penyakit, pengobatan, sampai tindakan yang dilakukan dokter. Semua itu harus dijaga kerahasiaannya, jika ada yang meminta harus seizin pasien dan menandatangani surat persetujuan pelepasan informasi.

Hal tersebut sesuai menurut Bab IV butir 2 Keputusan DIRJEN Pelayanan Medis Nomor:78/Yan.Med./RS.UM.DIK/YMU/1/91 tentang Petunjuk Pelaksanaan Penyelenggaraan Rekam Medis di Rumah Sakit, yang berbunyi: Isi rekam medis adalah milik pasien yang wajib dijaga kerahasiaan, untuk melindungi kerahasiaan tersebut.

b. Mengetahui Hak Pasien atas Informasi Medis dalam Rekam Medis di Rumah Sakit Islam AT-Tin Husada Ngawi.

Menurut data yang diperoleh dari hasil wawancara kepada dokter bahwa informasi yang diberikan dokter kepada pasien yaitu:

1. Informasi yang mengandung nilai kerahasiaan

Bedasarkan hasil survei di Rumah Sakit Informasi yang mengandung nilai kerahasiaan di Rumah Sakit Islam AT-Tin Husada Ngawi terdiri dari diagnosa pasien, anamnesa, pejalanan penyakit, catatan perawat, hasil pemeriksaan laboratorium atau rontgen, ringkasan keluar dan resume keperawatan. Semua hal yang berhubungan dengan diri pasien sedangkan pemberitahuan tentang penyakit pasien kepada keluarga harus dilakukan oleh dokter yang merawat.

Hal tersebut sudah sesuai dengan Depkes RI 2006 bahwa Informasi yang megandung nilai kerahasiaan yaitu laporan atau catatan yang terdapat dalam berkas rekam medis sebagai hasil pemeriksaan, pengobatan, observasi, atau wawancara dengan pasien. Informasi ini tidak boleh disebar luaskan kepada pihak-pihak yang tidak berwenang karena menyangkut informasi pribadi pasien secara langsung.

2. Informasi yang tidak mengandung nilai kerahasiaan

Berdasarkan hasil survei di Rumah Sakit Informasi yang tidak mengandung nilai kerahasiaan di Rumah Sakit Islam AT-Tin Husada Ngawi terdiri dari identitas pasien seperti nama, alamat, tanggal lahir, pendidikan, agama, pekerjaan dan lain-lain yang tidak mengandung nilai medis, walaupun demikian informasi ini juga tidak boleh dipublikasikan tanpa izin dari pasien.

Hal tersebut sudah sesuai dengan pasal 48 UU RI No.29 Setiap dokter atau dokter gigi dalam melaksanakan praktik kedokteran wajib menyimpan rahasia kedokteran, kecualii yang tidak mengan dung niali kerahasiaan meliputi nama, alamat, agama, umur dll.

Semua hal yang berhubungan dengan sakitnya pasien harus di informasikan baik dalam bentuk lisan maupun tertulis karena pasien berhak tahu. Selain itu dokter harus memberikan informasi kepada pasien baik yang diminta maupun tidak, kecuali pasien sendiri yang menolaknya, disini pasien berhak tahu 
penyakit dan tindakan apa saja yang harus dilakukan karena pasien mempunyai hak untuk mendapatkan informasi tersebut. Hal tersebut sudah sesuai Undang-undang No.36 tahun 2009 pasal 32 tentang Kesehatan.

Berdasarkan wawancara dengan 25 pasien, Bahwa sebagian besar pasien mendapatkan informasi tentang semua hal tentang keadaan penyakitnya yang telah disampaikan dokter tetapi masih ada juga pasien yang kurang paham tentang apa yang telah disampaikan dokter. Hal tersebut karena Pasien kurang mengerti apa yang disampaikan dokter.

Hal diatas telah sesuai dengan Prosedur tetap dan menurut pasal 32 Undang-undang No. 36 tahun 2009 , persetujuan tindakan medis dan persetujuan tindakan kedokteran di Rumah Sakit Islam AT-Tin Husada Ngawi.

c. Perlindungan Hak Pasien atas Penjagaan

Kerahasiaan isi Rekam Medis di Rumah Sakit Islam AT-Tin Husada Ngawi.

Berdasarkan hasil wawancara yang telah dilakukan dengan petugas URM di Rumah Sakit Islam AT-Tin Husada Ngawi diperoleh informasi:

a. Hak Tolak ungkap

Bedasarkan hasil survei yang dilakukan bahwa dokumen rekam medis harus dijaga kerahasiaannya dan tidak boleh dibaca atau diketahui oleh orang lain tanpa seizin pasien dangan yang boleh mengetahui hanya petugas yang berwenang. Hal teresebut sudah sesuai dengan Undang-Undang RI No.29 tahun 2004 tentang praktik kedokteran ada beberapa keadaan dimana pemegang rahasia dapat membuka rahasia tersebut tanpa dikenai sanksi hukum.

b. Hak Akses

Berdasarkan hasil survei yang dilakukan bahwa pasien boleh mengcopy data-data rekam medisnya sendiri untuk keperluan asuransi atau visum menandatangani surat pelepas informasi. Hal tersebet sudah sesuai dengan teori Guandi (2004) Hak akses merupakan hak pasien atau wewenangnya untuk melihat atau mengcopy data-data rekam medisnya sendiri.

c. Hak untuk mendapatkan informasi yang berkaitan dengan kondisi dan tindakan yang akan dilakuan terhadap dirinya.

Berdasarkan hasil wawancara yang dilakukan bahwa pasien mendapatkan informasi tentang kondisi dan tindakan yang akan dilakuakn oleh dokter atau tenaga medis lainya. Hal tesebut sudah sesuai dengan teori Guandi (2004) pasien yang mendapatkan pelayanan medis dari Rumah Sakit mempunyai hak untuk memperoleh ataupun menolak pengobatan. Informasi yang diberikan oleh setiap dokter adalah informasi yang lengkap, yaitu informasi yang akurat tentang perlu atau tidaknya suatu tindakan medis dilakukan dan resiko yang mungkin terjadi.

d. Hak Atas Privasi

Berdasarkan hasil wawancara yang dilakukan bahwa pasien mendapatkan haknya atas privasinya yaitu hubungan antara dokter dan pasien. Hal tersebut berdasarkan teori Guandi (2004) Hak ini bersifat umum dan berlaku untuk setiap orang dari hak ini adalah suatu hak atau kewenangan untuk tidak diganggu. Setiap orang berhak untuk tidak dicampuri urusan pribadinya oleh orang lain tanpa persetujuannya. Hal ini juga termasuk publisitas yang tidak kehendaki dan atas persetujuannya.

\section{SIMPULAN}

Berdasarkan pada hasil penelitian dan analisis data, maka penulis mengambil kesimpulan sebagai berikut:

1. Di Rumah Sakit Islam AT-Tin Husada, kepemilikan dokumen rekam medis di Rumah Sakit ada 3, yaitu : Milik rumah sakit, milik umum atau milik pihak ketiga, milik pasien.

2. Informasi yang diberikan dokter kepada pasien di Rumah Sakit Islam AT-Tin Husada tentang penyakit pasien sudah jelas dan sebelum dilakukan tindakan medis pasien harus mengisi lembar informed consent terlebih dahulu. Informasi medis yang diperoleh pasien disampaikan dokter atau tenaga medis dengan cara informasi tersebut diberikan dalam bentuk lisan tentang semua yang berhubungan dengan sakitnya pasien.

3. Perlindungan hak pasien atas kerahasian isi rekam medis di Rumah Sakit Islam AT-Tin Husada belum sesuai dengan teori yang ada, karena dokumen rekam medis tidak langsung di kembalikan ke unit filing dalam waktu 2x 24 jam.

4. Perlu dibuat SOP yang tegas terkait pengembalian dokumen rekam medis, dan di sosialisasi bagi petugas rekam medis secara masib.

5. Dokumen rekam medis pasien rawat inap segera di kerjakan dan segara dikembalikan ke bagian unit rekam medis. 
6. Peminjaman dan pengembalian dokumen rekam medis pasien rawat inap dibatasi dalam waktu 2x 24 jam.

\section{DAFTAR PUSTAKA}

Departemen Kesehatan RI. 2006. Pedoman Penyelenggaraandan Prosedur Rekam Medis Rumah Sakitdi Indonesia Edisi RevisilI. Jakarta: Depkes RI Direktorat Jenderal Bina Pelayanan Medik.

Firdaus, Sunny Umul. 2008. Rekam Medik Dalam Sorotan Hukumdan Etika. Surakarta: Lembaga Pengembangan Pendidikan (LPP) dan UNS Press.

Guwandi, J. 1992. Rahasia Medis. Jakarta: Fakultas Kedokteran Universitas Indonisia.

Indarwati. 2011. Perlindungan Hukum Terhadap Pasien Sebagai Konsumen Yang Mengalami Malpraktek Jasa Pelayanan Kesehatan. Malang: Universitas Brawijaya Malang.

Keputusan Dirjen Pelayanan Medik no. 78/Yanmed/RS Umdik/YMU/I/91 Tentang Penyelenggraean Rekam Medis di Rumah Sakit.

Notoatmodjo, Soekedjo. 2005. Metodologi Penelitian Kesehatan. Jakarta: PT. Rineka Cipta.

Peraturan Menteri Kesehatan Republik Indonesia Nomor269/Menkes/Per/III/2008. Tentang Rekam Medis/Medical Records. Rustiyanto, Ery. 2010. Etika Profesi Perekam Medis dan Informsi Kesehatan. Yogyakarta: Graha Ilmu.
Undang-undang Republik Indonesia Nomor. 29 tahun 2004 Tentang Praktek Kedokteran Edisi 2010. Yogyakarta: Aditya Pustaka.

Undang-undang Republik Indonesia Nomor. 36 tahun 2009 Tentang Kesehatan. Bandung: Citra Umbara.

Guwandi, J. 2004. Rahasia Medis. Jakarta: Fakultas Kedokteran Universitas Indonisia.

Websites: http://www.aidisindonesia.com/2012/10/ dua/pasangan-pasutri-dikaltim-di-usir (diakses pada hari jumat tanggal 21 Februari 2018 jam 22.19 WIB)

Kitab Undang-Undang Hukum Pidana Tentang Informasi bersifat rahasia. Undang-Undang Nomor 332 Tahun 2006. Undang-Undang Nomor 48 Tentang Tindakan Paksa Tindak Pidana. Undang-Undang Nomor 50 Tentang Ketentuan Undang-Undang Tindak Pidana. http://muvid.files.wordpress.com/2011/1 2/kuhp.pdf (diakses pada hari rabu tanggal 13 maret 2018 jam 14:48 WIB) https://www.google.com/search?q=mile $\underline{\text { s+dan+huberman }+2007 \& \text { ie }=\text { utf- }}$

$\underline{8 \& \text { oe }=\text { utf- } 8 \& \text { client=firefox-b }}$ (Miles dan Huberman. 2007. Metodologi Penelitian hari rabu tagl 13 Agustus 2018 jam 20.00 WIB)

https://www.google.com/search?safe=st rict\&client=firefox-b\&ei=lQTEW9POsTzvASM9ojABQ\&q=HARSONO+ METODELOGI+PENELITIAN+2008\& oq=HARSONO+METODELOGI+PEN ELITIAN+2008 